\title{
Affidamento fiduciario in San Marino: Proposal for the Commonwealth of the Independent States
}

\section{A. D. Rudokvas}

St. Petersburg State University, 7-9, Universitetskaya nab., St. Petersburg, 199034, Russian Federation

For citation: Rudokvas, Anton D. 2018. Affidamento fiduciario in San Marino: Proposal for the Commonwealth of the Independent States. Vestnik of Saint Petersburg University. Law 3: 370-382. https://doi.org/10.21638/11701/spbu14.2018.307

It is described in the article the construction of the institution of affidamento fiduciario, as it is present in the statutory law of the Republic of San Marino. The institution is a surrogate device of the true English trust, but at the same time, it absolutely corresponds to the civilian categories. Despite it is the institution of the law of contracts, is has been created on the base of such institution of the law of succession as fideicommissum. The author pays attention to the fact that the main distinction between the affidamento fiduciario on the one hand, and the institution of entrusted administration (or fiduciary management) of the post-soviet legal orders on the other hand consists in that the contract of affidamento fiduciario establishes a kind of program in the interest of the beneficiaries which cannot be eliminated by termination of the contract. In case of breach of his duties by the fiduciary it is allowed only to replace him with another person. That is why the affidamento fiduciario is much more stable construction than the entrusted administration. Therefore it protects better the beneficiaries' interest. Due to this the present writer as a drafter of the model law for the member-states of the Commonwealth of the Independent States "On entrusted administration and trust" borrowed the construction of the affidamento fiduciario as a model for the modification of the institution of the entrusted administration of property.

Keywords: trust, affidamento fiduciario, fideicommissum, San Marino, Commonwealth of the Independent States, civil law, Russia.

\section{Introduction. Origin of the Construction of Affidamento Fiduciario.}

The original construction of the affidamento fiduciario as a civilian alternative to the institution of trust has been developed by an Italian comparative law professor Maurizio Lupoi who since 2012 to present is the President of the special state Court for the trust and the fiduciary relations of the Republic of San Marino.

His studies in comparative legal history led him to an astonishing revelation that is contrary to popular belief. Lupoi maintains that trusts in England originated from European Continental law in the Middle Ages and traces the ancestor of the trust in the fideicommissum confidentiale that was to be found in Continental Europe since the first developments that occurred after the glossators made their Gloss to the Corpus Iuris Civilis. It means that the trust is not an original institution of the English law, but it is a legal transplant from the Continent. This surprising discovery became the reason for the innovative conceptualization of trust by Maurizio Lupoi.

His monograph published in Italian in 1994 under the title "The Origins of the European Legal Order"(Alle Radici del Mondo Giuridico Europeo) became a starting point for

(C) Санкт-Петербургский государственный университет, 2018 
the development of the issue in a certain sense. The book is a comprehensive reappraisal of thinking on the common structural features of the various European jurisdictions. It was named "The Law Book of the Year" in Italy in 1995. Already in 2000, it was published in English translation by the Cambridge University Press.

The most complete presentation of the thesis of the continental origins of the English trusts one can find in his article "Trust and Confidence" (Lupoi 2009, 253-287). But most of the material was already in his previous essays (Lupoi, 1999, 967-988).

As a practical result of his research, the professor Lupoi then proposed a new type of contract (contratto di affidamento fiduciario) that would accomplish in purely civil law terms what had become the functions of trusts in the common law.

That was accepted by the Republic of San Marino (Lupoi 2011, 51-59). Its Parliament passed a law on "affidamento fiduciario" in 2010 (Repubblica di San Marino, Legge 1 marzo 2010 n. 43 "L'istituto dell'affidamento fiduciario". Accessed February 10, 2018. http://www.cortetrust.sm/on-line/home/legislazione/articolo48007035.html). The statute (hereinafter simply the Law) had been drafted by the professor Lupoi. The Law was enacted synchronically with the adoption of another law of San Marino on trusts (Repubblica di San Marino, Legge 1 marzo 2010 n. 42 "L'Istituto del Trust". Accessed February 10, 2018. http://www.cortetrust.sm/on-line/home/legislazione/sul-trust.html). The coexistence of these similar institutions in the same legal order provoked their competition.

The next step was to justify the theory supporting this new type of contract. It was to explain that it had nothing to do with the German institution of the fiduziarische Geschäfte or with Roman law fiducia cum amico or fiducia cum creditore.

San Marino (as Italy) adhered long ago to the Hague Convention on the Law Applicable to Trusts and on Their Recognition of 1985 ( Repubblica di San Marino, Decreto Consiliare 20 settembre 2004 n. 119 "Adesione alla Convenzione sulla Legge applicabile ai Trusts e sul loro riconoscimento fatta all'Aja il $1^{\circ}$ luglio 1985”. Accessed February 10, 2018. http://www.cortetrust.sm/on-line/home/legislazione/articolo48007034.html). In course of its implementation, both these countries allowed the creation of the domestic trusts and provided party autonomy in the choice of the law applicable to them (Graziadei 2012, 29-82). That is why the academic works of the professor Lupoi had a lot of clout with the formation of the trust law enforcement in Italy.

Aiming at a further advance of the original construction which he created and drawing on the experiences of its application in practice with his assistance, the professor Lupoi recently published a monograph Il contratto di affidamento fiduciario, Milan, 2014 (Lupoi, 2014, 1-500).

His efforts resulted in that Italian Parliament included the "contratto di affidamento fiduciario" among the legal relationships available to protect handicapped persons in a statute passed in 2016 (Law No. 112) (Maciocchi 2017).

Taking into consideration the interest of the civil law jurisdictions in borrowing of trusts or in providing of viable trust-like devices in the conceptual framework of the civilian tradition, the original construction of the affidamento fiduciario evidently has good prospects of its further implementation in other countries.

\section{Main text. Main Features of the Construction of Affidamento Fiduciario in San Marino.}

The expression contratto di affidamento fiduciario is a combination of words which had never appeared in Italian legal literature before the publication of the texts written by 
Maurizio Lupoi. In the context of the legislation of San Marino this phrase can be translated into English as 'entrustment'.

The construction is similar to trust but it stands enough far from such constructions as 'purpose designed assets' (vincoli di destinazione) in the contemporary Italian law or the fiducia of the Roman law and the modern derivatives of the latter.

In fact when M.Lupoi discovered in course of his comparative historical studies that the principles of the English trust ascended to the Roman and Canon Continental ius commune of the XIV-XVII centuries he revealed that they were elaborated in it in application to the testamentary dispositions. The law of succession remained for many centuries the main sphere of application of the concept of 'fiduciarius'. That is why the professor Lupoi created the same construction under the law of contracts while preserving the nature of the institution which derives from the dispositions mortis causa. Such is indeed the cause of similarity between the core structures of the English trust on the one hand, and of the construction of the affidamento fiduciario (which is based on the principles of the ius commune as the law applicable in San Marino until now) on the other hand (Lupoi 2011, 51; On the contemporary application of the ius commune in San Marino see e.g.: Di Bona 2015).

Under the section 1 of the Article 1 of the Law, affidamento fiduciario is a contract (l'affidamento fiduciario e il contratto), by which a person who transfers his property into affidamento fiduciario, and is to be referred to as affidante, and the fiduciary, who is to be referred to as the affidatario, "agree on a program that dedicates certain assets and the advantages deriving from them» (convergono il programma che destina taluni beni e i loro frutti) for a period not exceeding 90 years, to one or more beneficiaries, who may but need not be party to the contract. Thus, the temporary but possibly long-term character of the affidamento fiduciario is a characteristic feature, which assimilates this institution with the English trust.

Nevertheless, it is impossible not to admit that the above-mentioned legal definition of the affidamento fiduciario as a contractual relation per definitionem seems to be rather paradoxical against a background of the Article 14 of the Law, with its head: "Affidamento fiduciario created by will". Under the provisions of this article, if the affidamento fiduciario is created by will, subjecting an heir, a legatee or a testamentary executor to the obligation to carry it out, the provisions of this Law shall be followed so far as applicable, that is as far as the application of these provisions, which are aimed first of all to the contractual relations, should not conflict with the nature of the relations arising from inheritance. So it turns in the upshot that the affidamento fiduciario can be created mutatis mutandis also by will. Hence it is not an institution of the law of contracts exclusively.

For the better understanding as of the last circumstance as of the degree of relationship of the institution of the affidamento fiduciario with the transactions inter vivos, one should remember that the affidatario becomes a 'temporary owner', that is he is a temporary title holder, who is obliged to exercise the right granted to him in the interests of the beneficiaries exclusively and not in his own interest. This temporary title holding is only a mean which he should apply to compass the purpose determined under the terms of the contratto di affidamento fiduciario.

At the same time, the settler (affidante) who transferred the assets to the affidatario under the contratto di affidamento fiduciario forfeits the rights of infighting pressure on the affidatario, the right to modify the terms of the contract or its purpose, the right to apply any contractual sanction unless it is provided under the Law. That is why the legal 
relations similar to those which arise from the mandatum or fiducia cum amico under the Roman law and their modern derivatives never arise between the affidante and the affidatario under the contratto di affidamento fiduciario.

This is understandable because the set of facts of the given transaction is typologically ascending to the construction of the fideicommissum in the ius commune. Under this testamentary disposition the dead testator simply did not have a chance to claim the fiduciary for the breach of his fides by the non-performance of the disposition under which the latter was a temporary title holder. This peculiarity of the construction of the affidamento fiduciario makes it much different from all the types of contract known in the civil law but assimilates it to the English trust (Lupoi 2017, 736-738).

The affidatario under the affidamento fiduciario does not act 'at the expense' or all the more 'on behalf' of somebody. He is dominated by the interest of the beneficiaries and not by that of the settler of the affidamento fiduciario (even if the latter is still alive and under this point, the given relation differs from the unalloyed fideicommissum). The legal relations arisen between the affidatario and the beneficiaries shall not be terminated in the event of death or incapacitation of a party. Non-performance or undue performance by the affidatario of his duties always has as a consequence another sanction than the termination of the relations of the affidamento fiduciario. In such way, these legal relations consistently survive until the exhaustion of the purpose of the settlement (Lupoi 2017, 739).

The assets in affidamento fiduciario can be current or future assets. They can be ascertained or ascertainable. The assets can be transferred to the affidatario by the affidante or by third parties, who are outsiders of this contract. The assets can belong to the affidatario himself also and can be settled by him. In the last situation the latter, on the one hand acting as the affidante, dedicates certain part of his own assets and the advantages deriving from them for the beneficiaries, and on the other hand he himself as the affidatario, fulfils the above-mentioned "program", that is - the destination established by him for these assets (section 2 Article 1 of the Law).

Since the affidamento fiduciario is a contractual construction, the affidante can declare himself to be affidatario only provided that at least one beneficiary is party to the contract (section 1 Article 2 of the Law). But in any case, he can do that only on a temporary basis (temporaneamente). Consequently it should inevitably take place a substitution of the original affidatario for another person. A legal mechanism provided for the necessary substitution of the affidatario as in the given situation, as under other circumstances, will be described at a later stage.

In other occasions, the affidante and affidatario are the parties to the contract. At the same time, the beneficiaries can also be contracting parties, transforming the contract in that way into a multilateral one. But this is not obligatory. Thus the beneficiaries acquire the rights arising from the contract or as the parties of the latter, or as the third parties for the benefit of which the contract has been concluded.

Under the section 3 Article 1 of the Law: «the affidamento fiduciario is presumed to be gratuitous». This formulation is a little bit different from the theoretical postulate of M. Lupoi that the impossibility to derive any personal benefit from the assets transferred to affidatario under the title of affidamento fiduciario is a conditio sine qua non of this institution. That is an idea the affidatario is never entitled to use for the own benefit the assets transferred to him in the interest of the beneficiaries (Lupoi, 2017, 740). 
Nevertheless, the wording of the law of San Marino presupposes a possibility to provide in the contratto di affidamento fiduciario a reward for the affidatario, that is, his entitlement to benefit from his position of the affidatario. On the other hand, under the section $5 \mathrm{Ar}$ ticle 4 of the Law, the affidatario may be one of the beneficiaries. Such an approach again does not comply with the idea that the affidatario should never be entitled to derive personal benefit from the assets transferred to him under the title of affidamento fiduciario.

At the same time, in order to render tribute to the doctrinal construction, the legislator of San Marino under the Article 18 of the Law provided that the affidatario, who, in breach of contractual or other legal obligations applicable to his position, uses the assets of the dedicated patrimony (patrimonio affidato) for his own or another's benefit (a proprio o altrui profitto) or delays their transfer to those beneficiaries entitled, shall be punished by imprisonment and disqualified from acting as fiduciary.

The contratto di affidamento fiduciario shall be invalid unless it is in writing and accompanied by the opinion of a Notary Public admitted in San Marino certifying its validity. In such way, this Notary Public is in charge of control that the content of the given contract satisfies the requirements of the law applicable (section 4 Article 1 of the Law). At that one should bear in mind that the contratto di affidamento fiduciario does not burden the assets - it obliges the person of the affidatario, but only as a result of the real transfer of title over the entrusted property to him. Hence the transfer of title belongs to the set of facts of this transaction. On the other hand, witness evidence in relation to declarations and/or agreements subsequent to the conclusion of the contratto di affidamento fiduciario or, in the case of the affidamento fiduciario created by will, subsequent to the testator's death, shall always be admissible (Article 17 of the Law).

Another important feature of the given legal relation is the segregation of the assets transferred in affidamento fiduciario from the personal belongings of the affidatario. A mixture of these different property holdings would make it extremely problematical as any judgment on if the affidatario gets a personal benefit from the assets transferred to him in affidamento fiduciario (which he is not entitled to get), as any evaluation of the due performance of the 'program' of use of such assets in the interest of the beneficiaries which is inherent in the contract.

The assets transferred to the affidatario into affidamento fiduciario or settled (beni... vincolati) by him for the purpose of implementing the contractual program constitute a dedicated patrimony (patrimonio affidato). Neither the transfer of assets into affidamento fiduciario, nor the owner's unilateral declaration of the transformation of a definite part of his assets in patrimonio affidato needs comply with the formal requirements required for gifts or be confirmed before the court (section 1 Article 3 of the Law).

The assets forming part of a dedicated patrimony shall be both segregated from those owned by the affidatario in his personal capacity and identifiable as such. Any registration in public registries shall state that the assets form part of the patrimonio affidato (section 5 Article 3 of the Law).

Testimonial evidences, as well as references to the kind of trade exercised by the person who transferred assets in the affidamento fiduciario, are sufficient to prove that concrete chattels corporeal which are situated in a house or a plant form part of the assets of the patrimonio affidato. Those law-blanks of the contratto di affidamento fiduciario which are used in practice normally specify the duty of the affidatario to document every acquisition of assets with a precise indication of its date (Lupoi 2017, 744). 
The contract may give a name to the patrimonio affidato (section 4 Article 3 of the Law).

The patrimonio affidato belongs temporarily (for the contractual time-period) to the affidatario on the title of ownership. Therefore he may, subject to the terms of the contratto di affidamento fiduciario, exercise over it any of the rights and powers of an absolute owner. But due to the fact, that the assets are only in the fiduciary ownership of the affidatario, the patrimonio affidato has its specific legal regime. This dedicated property is separate and distinct from the personal assets of the affidatario. That is why it is not affected by his matrimonial property regime and is not subject to any claims by his heirs or his creditors.

The assets in the patrimonio affidato can only be subject to execution in relation to obligations arising in connection with the contractual program of affidamento fiduciario itself (section 2 Article 3 of the Law). In the event that the rights of the beneficiaries do not extend to the entirety of the dedicated patrimony, a separate right to the excess arises. The affidante (but not the affidatario!) shall be entitled to the excess of the assets and their products. The entitlement exists to the extent that and for so long as such excess persists (section 4 Article 5 of the Law).

The role of affidatario can be played by one or more persons. Where the contract appoints two or more fiduciaries (affidatari), they hold the assets jointly. Upon the first death, the dedicated patrimony will accrue to the one or more surviving fiduciaries by survivorship (sorge fra essi una comunione a mani unite col regime dellaccrescimento) section 3 Article 3 of the Law.

The contratto di affidamento fiduciario shall identify the beneficiaries or provide the criteria for their identification. It shall also determine the rights of the beneficiaries in the patrimonio affidato and its products. Inter alia the contract shall determine under what circumstances the rights of a beneficiary under the contract shall or may come to an end (section 1 Article 4 of the Law). As long as at least one beneficiary is mentioned in the contract it may be provided by the contractual terms that the affidante may nominate other beneficiaries at a later stage (section 2 Article 4 of the Law).

It may be provided under the contract that the affidatario or a third party may determine which of several persons named in the contract or which members of a family or class of persons named in it shall become beneficiaries. Besides the contract may provide, that the affidatario or a third party may determine the rights of beneficiaries, provided that the beneficiaries are different from the persons entitled to exercise such determination (section 3 Article 4 of the Law).

It is allowed under the law nomination as beneficiaries of lineal descendants of a person living at the time when the contract is made, although they might not yet have been conceived (section 4 Article 3 of the Law). The affidante may be a beneficiary. The affidatario may also be a beneficiary, but only as one of the several beneficiaries (section 5 Article 3 of the Law).

Under the Article 5 of the Law, which bears a characteristic head "Implementation of the contractual appropriation program" (Attuazione del programma destinatorio), are determined essential terms of the contratto di affidamento fiduciario.

Besides the previously mentioned requirement of indication of the beneficiaries and their rights to benefits in the contract, the Law provides a few other contractual terms as essential for the given type of contract. It should be determined in such contract (il contratto determina), in what kind of cases the prior consent of the affidante or of a person 
appointed by him is required for the affidatario to carry out a valid act. The contract shall also provide under what circumstances in the contractual relationships arising out of the contract the affidatario can be replaced or joined by others to hold the assets jointly (the last words refer to the comunione a mani unite col regime dellaccrescimento under the above-quoted section 3 Article 3 of the Law).

Above all, it is required under the Law to provide in the contract those circumstances, under which the affidante or a person appointed by him is authorized to assign to another person the benefit and the burden of the contract, free of any and all claims by the affidatario, and to carry out all acts and execute all documents in connection with the patrimonio affidato. This rule is an exception to the general provisions of the ius commune as a normative system applicable in San Marino. Finally, the contract shall provide when the affidatario may act despite a conflict of interest.

At the same time even where the contract does not so provide or provides otherwise in the event of a breach by the affidatario of his duty, the affidante or the person appointed by him may exercise power to assign to another person the benefit and the burden of the contract, and the other powers referred to in the previous paragraph. The application of these measures does not prejudice to the duty of the affidatario to make losses good.

If the affidatario dies or becomes incapacitated and a new affidatario has not been appointed, or if the affidatario desires to be discharged from his duties, the affidante or the person appointed by him not only may but must exercise the powers referred to above (Article 5 of the Law).

On the other hand, unless otherwise provided by the contract, the rights and powers conferred on the affidante cannot be exercised by his heirs, and neither are they subject to his obligations (section 2 Article 2 of the Law).

In such way, the Law provides an original remedy of 'self-defence' for the persons interested in a performance by the affidatario of his duties. This provision can seriously decrease the need for the intervention of the court in an eventual conflict. Such an individual style of the 'self-defence' is one of the fundamentals of the construction of affidamento fiduciario along with another specific feature, which a creator of this construction M.Lupoi names the "program" which is inherent in the contratto di affidamento fiduciario.

The given contract is "a polyfunctional structure and therefore - a combination of invariant terms composing it, some of which are essentials, and others - facultative and causally irrelevant as appropriate; the structure becomes a legal relation when it is placed at the service of a definite program which vitalizes it in the framework of a contract for which it forms the causa" (Lupoi 2017, 738).

The said 'program' defines the main interests of the beneficiaries to satisfy them under the given contract. If necessary it determines the gradation between them that is their relative importance. In such way, it appears the measure of the lawfulness of the parties' behavior in the legal relation. Upon the point, the civilian construction differs radically from the English trust because the just mentioned causa is not only present in the contratto di affidamento fiduciario, but should be openly manifested in it without fail.

The affidante - a person transferring the assets into the affidamento fiduciario offers the 'program'. The affidatario assumes the obligation to implement the 'program' under the terms of the contract. The parties of the contract are the persons mentioned above, but its parties can become also a guarantor (an analog of the trust protector or the 
trust enforcer) and some of the beneficiaries or all of them (in difference from the English trust). The role of the guarantor is particularly important for the long-standing contracts because he may intervene to resolve a conflict, which is not provided for by the contract (and therefore its consequences are not regulated by the contractual terms). Certainly, it is impossible to provide in a contract for the whole diversity of hypothetically possible situations. The guarantor may render assistance to the affidatario, authorizing his most important acts, intervening in his free disposition of the assets and regulating his eventual conflicts with the beneficiaries (Lupoi 2017, 744).

The structure of the affidamento fiduciario is a stable one because the contract cannot be terminated except in the event of impossibility of performance. The conclusion of such a contract means at the same time a preventive waiver of the right to terminate it. The waiver subordinates a private interest of any contracting party to the purpose of implementation of the 'program' which is inherent in the contract. There exist alternative remedies on default or supervening undue hardship of performance, because the termination of the contract could result in abrogation of the 'program', created by it, which would lead to the foundation failure of the given legal relation.

The said remedies are the means of self-defence thus excluding the intervention of a court. They exist due to the presence in the internal structure of the contratto di affidamento fiduciario of such separate component as the "deal of empowerment" (negozio autorizzati$v o$ ). The deal empowers the authorized person as to dispose of the assets transferred into the affidamento fiduciario, as to replace the original affidatario by another person. It is intended that if the agreement on the transfer of the assets into the affidamento fiduciario to a definite person takes place, the contracting parties accept in anticipation an eventual replacement of the latter by another person. A person authorized under the deal of empowerment can be as the guarantor, as the party transferring the assets into the affidamento fiduciario (the affidante). But the beneficiaries or one of them can become also persons authorized under the deal of empowerment. This original protective mechanism makes the institution of the affidamento fiduciario very different from the English trust (Lupoi 2017, 739).

To be fair one should notice that the Law still provides a few cases of the early termination of the contratto di affidamento fiduciario. Along with the provision under the section 5 Article 1 of the Law that the contract cannot be terminated, the legislator makes a clause: except in the event of impossibility of performance. Furthermore under the provision of the section 3 Article 5 of the Law, so soon as it is known that there is no beneficiary and there is no possibility that any beneficiary may be appointed or come into existence before the expiry of the contract term, the contract shall come to an end. In such a situation the patrimonio affidato shall be returned to the affidante.

If the mechanism of the 'self-defence' doesn't work the court on the application of any interested person and, if appropriate, after having made any necessary investigations, may intervene in the situation by its reasoned judgment. It can happen so if there is no longer the affidante or any person appointed by him, or if there is, but he fails to act. But the termination of the affidamento fiduciario by the court is absolutely excluded also in the given case. Instead of it, the court may only make any decisions that may be required in the exercise of the powers set out under the Law for the affidante or any person appointed by him. It means that the court may assign to another person the benefit and the burden of the contract, free of any and all claims by the affidatario. It may also carry out all acts and execute all documents in connection with the patrimonio affidato. 
However the court may also give directions to the affidatario how he shall exercise his rights under the contratto di affidamento fiduciario. These directions are aimed at the achievement of the purpose of this contract in the context of the changed circumstances. For the same reason, the court has the power to vary the contract by adding new provisions or amending or deleting existing provisions, where this appears desirable to achieve the contractual program under the change of position (Article 16 of the Law).

Due to the reason that the duties of the affidatario are the core structure of the abovementioned 'contractual program', the legislator described their content enough in detail. The affidatario must act fairly and in good faith (secondo correttezza e buona fede) - section 1 Article 6 of the Law. In performing his obligations under the contract the affidatario shall act in his capacity of affidatario. As such he shall act in the beneficiaries' interest. In a performance of the obligations, the affidatario shall observe the same standard of care that a reasonable person (bonus paterfamilias) would be expected to observe in relation to his own assets in similar circumstances. But if the affidatario is acting professionally as such, he shall observe the same standard of care that it is reasonable to expect from such a professional (section 2 Article 6 of the Law).

The affidatario must provide a full account of his activities to the persons indicated in the contract. Besides, he must provide this account in any event to the beneficiaries, according to their interests. It can not be excluded by a contract term the right of the beneficiary to receive a full account (section 3 Article 6 of the Law). The contract may provide that the affidatario may assign the benefit and the burden of the contract to another person. In this event, the latter becomes a new affidatario. The assignment can take place at the own instance of the affidatario or with the prior consent of the affidante or of the person appointed by him (section 4 Article 6 of the Law).

The rights of the beneficiary against an affidatario shall be prescribed after 10 years have elapsed. This time period starts from the time when the beneficiary became aware of the facts on which his claim is based (egli ebbe notizia del fatto sul quale si fonda la sua pretesa) - section 1 Article 15 of the Law.

The affidatario shall be liable for the acts of any consultants, agents, managers or delegates appointed by him for exercising of the affidamento fiduciario. This liability exists notwithstanding any provisions in any contract between them aiming at excluding or limiting his liability.

But the liability is applicable unless the consultants, agents or delegates have been chosen and appointed by the affidatario observing the same standard of care that he would have exercised in relation to his own assets in similar circumstances.

Above all if the actions of the above-listed persons are the result of dolus, gross negligence or bad faith, the liability of the affidatario takes place in any case (section 1 Article 7 of the Law).

It shall be void any provision of the contract which is aimed to exclude or limit in advance the liability of the affidatario for dolus, gross negligence or bad faith.

By the same token it shall be void a contractual provision which excludes or limits in advance his liability generally for acts carried out where a conflict of interest exists.

The affidatario shall be also liable for the acts which are unauthorized under the contract even if a provision of the contract excludes or limits in advance his liability for such acts (section 2 Article 7 of the Law). 
In addition to any contractual damages to which the affidante and the beneficiaries are entitled as a result of the loss suffered, the affidatario shall be bound to restore the patrimonio affidato. It shall be restored to the value it would have had, had no breach of the contract occurred (section 1 Article 8 of the Law).

Even if no loss has been caused to the beneficiaries, the affidatario shall surrender to the patrimonio affidato any benefit improperly obtained from his position as affidatario (section 2 Article 8 of the Law).

Before they enter into a contract with the affidatario, third parties dealing with him are entitled to require the latter to demonstrate his powers and to supply them a copy of the relevant provisions of the contratto di affidamento fiduciario, duly certified by him (section 1 Article 9 of the Law).

Any restrictions on the authority of the affidatario are binding on third parties if they are aware of such restrictions. But such restrictions are also binding on them if they are unaware of these restrictions through their own fault (section 2 Article 9 of the Law). Third party claims against the affidatario can only be enforced against the property in patrimonio affidato. It does not matter if the claims are arising in contract, tort or by operation of law. However, the affidatario is personally liable, where he, in dealing with a third party, did not hold himself out as affidatario. But in such a situation his personal liability is accompanied with a right to recoup himself out of the patrimonio affidato (section 3 Article 9 of the Law).

Any legal or administrative act of an affidatario which has the effect of reducing the property in patrimonio affidato shall be invalid if it is satisfying one of the following conditions: a) the act is donative and it is made neither pursuant to a contractual obligation nor in the exercise of power given to the affidatario, b) the act is beyond of those limits of the authority of the affidatario, which are binding on third parties, c) the act is causing loss to the patrimonio affidato because the consideration received by the affidatario for goods or services (or for both them) is much lower than their actual value, d) the act is carried out despite a conflict of interest unauthorized in the contract (section 1 Article 10 of the Law).

However in the absence of the above-mentioned breach of law the affidatario is entitled to any disposition of assets transferred in the affidamento fiduciario.

When the affidatario is making a dispositive transaction which he is entitled to under the contract, he transfers a greater right than he himself has. He transfers to another person a perfect title and not the restricted and temporary title which he holds himself. On the contrary, everything he acquires in his capacity of the affidatario (e. g. a purchase price for the sold goods) receives the same legal regime as the other components of the assets transferred to him in the affidamento fiduciario (Lupoi 2017, 742).

The invalidity of a dispositive act relating to assets of a patrimonio affidato results in invalidation of any subsequent dispositive act of the same assets or their substitutes. Nevertheless, it does not prejudice any rights acquired by third parties in good faith, for consideration and without notice of the cause of invalidity, unless a restriction has been entered in the relevant registry in connection with a claim (salvi gli effetti della trascrizione della domanda giudiziale) - section 2 Article 10 of the Law.

An invalid act can be validated. The validation is possible with the consent of all beneficiaries, provided that all the beneficiaries are in existence and ascertained (purche altri beneficiari non possano sopravvenire ) - section 3 Article 10 of the Law. 
Under the Law of San Marino there are several special provisions aimed to block the possibility to exert the affidamento fiduciario for the circumvention of law, in particular of its provisions related to the share of a forced heir, limitations on a gift, the inadmissibility of the pretended transfer of assets in the fiduciary ownership to retain operative control over it.

From the content of the Article 11 of the Law it follows that the transfer of assets into affidamento fiduciario shall amount to a gift if the contractual or a testamentary affidamento fiduciario takes place in favor of beneficiaries who are vulnerable individuals. These are disabled people, chronologically gifted persons older than 75 years, men incapable or incapacitated those who are drug or alcohol addicts or invalids affected by a serious chronic disease.

The given Article of the Law acknowledges only one exception from this rule, namely, so long as the assets of the affidamento fiduciario the subject matter of the disposition, have been transferred or settled (beni...vincolati) by the affidante, who is a spouse of the beneficiary, or his blood relative no more remote than the third degree. Under this provision of the Law it is allowed also that the affidante can be the beneficiary's mother- or father-in-law or brother- or sister-in-law. What is more required for the exception the assets should not be manifestly excessive with respect to the needs of the beneficiary. If the patrimony dedicated to the needs of the beneficiary is evidently excessive from this point of view, any excess being regarded as a gift.

Where the contract involves the making of gifts and it has not been fully performed forced heirs (legittimari) can take action. This action is aimed only to protect the share to which the claimant would be entitled as a forced heir. The action can be brought against the affidatario as well as against beneficiaries as recipients of the gifts, if they are in existence and ascertained (section 1 Article 12 of the Law).

Meanwhile those persons who are beneficiaries in the sense of the Article 11 of the Law (deboli, that is invalids, or aged men older than 75 years, or those individuals who are incapable or incapacitated, or drug or alcohol addicts) can bring a claim as the forced heirs only if the assets belonging to the patrimonio affidato existing in favor of them are clearly not sufficient for their needs (section 1 Article 12 of the Law).

The Article 13 of the Law provides the protection of personal creditors of the affidante in the situation of the transfer of assets in affidamento fiduciario aiming at the concealment of these assets. Such creditors may challenge acts transferring assets to the affidatario or settling such assets by the affidatario himself as the affidante, if the contract has not been fully performed.

The action can be brought not only against the affidatario, but also against the beneficiaries having rights in the transferred assets (if the beneficiaries are in existence and ascertained) as if the transfer had been made directly to them (section 1 Article 13 of the Law). The grounds for the claim may exist either in relation to the affidatario or in relation to one of these beneficiaries (section 2 Article 13 of the Law). The limitation period for such claims is 5 years (section 3 Article 13 of the Law).

\section{Conclusion. Perspectives of Implementation of the Affidamento Fiduciario in the Legal Orders of the Member-States of the Commonwealth of the Independent States.}

One of the preconditions for the creation of an enabling investment climate in Russia and other member-states of the Commonwealth of the Independent States is the imple- 
mentation of those competitive legal mechanisms which give a chance to win the jurisdictions of common law in the global 'competition of jurisdictions'.

That is why on the cabinet council of the Government of the Russian Federation on 25 March 2015 the President of Russia Vladimir Putin proclaimed: "We are creating organizations that we never provided before in the Russian legislation. These are trusts, including also the so-called irrevocable trusts, when a citizen transfers his assets to a management company and from this moment at the bottom of fact he ceases to be the owner of them". In his opinion, the innovation should seriously contribute to the creation of a favorable climate for business under the Russian jurisdiction (Latukhina 2015).

But the legislative reform announced by the Russian President in 2015 is not turned to life until now. The blocking of the reform is caused by the unanimously negative attitude of the main representatives of the Russian civil law doctrine even to the idea of implementation of the English institution of trusts in Russia.

They say that the true English trust can be adequately described only in the framework of the concept of the "divided ownership". Under this conceptual framework the beneficiary as the "equitable owner" has rights to the utility of the assets in trust, but all the other rights of ownership related to the same assets belong to the trustee as a "formal owner", who is obliged to exercise these rights in the interest of the beneficiary, and not in his own interest.

Based on this assumption they conclude that the implementation of English trust in the civil law is inadmissible. The conclusion is based on the premise that the concept of 'unitary' ownership which is a cornerstone of the law of property in the civilian tradition makes it logically impossible even to imagine a splitting of the right of ownership into fragments belonging to different owners (see for details: Rudokvas 2017, 49-70).

As is generally known due to the transplant rejection of trusts in the civil law doctrine of the post-Soviet legal orders the last-mentioned have only an institution of the entrusted administration of property as a functional surrogate device of trust which does not provide the transfer of title to the entrusted administrator. This contractual institution is sometimes referred to in English as a "contract of fiduciary management" (Russell and Shakhnazarov 2017, 936-943).

It seems that a modification of the entrusted administration on the model of the institution of affidamento fiduciario would transform it into a really viable substitute of trust and in such way make it useless any form of transplantation of the latter in the domestic legal order.

Under this aspect, it does not matter that in case of the affidamento fiduciario the transfer of title is concerned, but the entrusted administration is only about the transfer of power of exercise of right belonging to the settler.

As noted by Maurizio Lupoi: «The temporary nature of the affidamento fiduciario is its indispensable feature. Another specific feature of it is the submission of the affidatario to the regulatory power of the person, which is authorized under the negozio autorizzativo. And the third feature is the impossibility for the affidatario to gain personal benefit deriving from the assets transferred to him in affidamento fiduciario. Even if a statutory provision provides the transfer of ownership to the affidatario, the presence of these features of his legal position makes it impracticable to discuss if the affidatario is a true owner or the nature of his title derives from the law of obligations. After all the contratto di affidamento fiduciario does not encumber the assets, but it obliges a person, even if only as a consequence of the real transfer of assets to him» (Lupoi 2017, 740). 
That is why the present writer as a drafter of the model law for the member-states of the Commonwealth of the Independent States "On entrusted administration and trust" has proposed the modification of the institution of the entrusted administration of property in the spirit of the construction of the affidamento fiduciario. In the event of adoption of this model law by the Inter-parliamentary Assembly of the CIS, which is planned for the 2018, the legislators of the member-states will have a good reason to think about the desirability of modernization of their domestic legal provisions on the entrusted administration of property to follow the pattern of the affidamento fiduciario. It is very obvious that the last one is much more stable construction than the entrusted administration, and this stability is explainable by taking care of the interests of the beneficiaries.

\section{References}

Di Bona, Laura. The 'model' of San Marino and the development of the tradition [Il «modello» sammarinese e le fughe in avanti della tradizione]. Accessed February 10, 2018. http://www.cortetrust.sm/on-line/ home/in-evidenza/a--symposium-san-marino-22nd--23rd-may-2015.html.

Court for the trust and the fiduciary relations of the Republic of San Marino "Giudici”. Accessed February 10, 2018. http://www.cortetrust.sm/on-line/home/i-giudici.html.

Graziadei, Michele. 2012. Recognition of common law trusts in civil law jurisdictions under the Hague Trusts Convention with particular regard to the Italian experience. Re-imagining the Trust. Trusts in Civil Law, edited by Lionel Smith, 29-82, Cambridge University Press.

Latukhina, Kira. Putin Supported the Proposal for the Amnesty of Capital [Путин поддержал предложения по амнистии капиталов] / Российская Газета RG. RU 25.03.2015. Accessed February 10, 2018. https://rg.ru/2015/03/25/kapitali-site.html/.

Lupoi, Maurizio. 1999. “The Civil Law Trust”. Vanderbilt Journal of Transnational Law, 32: 967-988.

Lupoi, Maurizio. 2000. The Origins of the European Legal Order. Cambridge University Press.

Lupoi, Maurizio. 2009. "Trust and Confidence”. Law Quarterly Review 125: 253-287.

Lupoi, Maurizio. 2011. "The New Law of San Marino on the 'Affidamento Fiduciario". Trust Law International 25: 51-59.

Lupoi, Maurizio. 2014. Contract of 'affidamento fiduciario' [Il contratto di affidamento fiduciario]. Milan, Giuffre Editore.

Lupoi, Maurizio. 2017. "The reasons for the doctrinal proposal of the 'affidamento fiduciario" [Le ragioni della proposta dottrinale del contratto di affidamento fiduciario]. Contratto e Impresa 3: 734-745.

Maciocchi, Patrizia. 2017. “Contract of 'affidamento fiduciario': free way for judge to take care of a condition of a will" [Contratto di affidamento fiduciario: via libera del giudice tutelare sul "Dopo di noi"]. Norme e Tributi. Accessed February 10, 2018. http:/www.ilsole24ore.com/art/norme-etributi/2017-03-03/contratto-affidamento-fiduciario-via-libera-giudice-tutelare-dopo-noi-152658. shtml?uuid=AEFOOPh\&refresh_ce $=1$.

Russell, David, and Karen Shakhnazarov. 2017. "Russia - a new province for trust law?” Trusts \& Trustees 23 (9): 936-943.

Rudokvas, Anton. 2017. “Trust and Fiduciary Ownership in Russia”. KLRI Journal of Law and Legislation, 7 (2): 43-70.

Received: 25.02 .2018

Accepted: 30.05.2018

Author's information:

Rudokvas Anton D. - Dr. Sci., Professor, Associate Professor; rudokvas.a@jurfak.spb.ru 